\title{
A CONSTRUÇÃO DA CRÍTICA EM RESENHAS PRODUZIDAS POR ALUNOS
}

\author{
Flávio Luis Freire Rodrigues* \\ Universidade Estadual de Londrina \\ Londrina, Paraná, Brasil
}

\begin{abstract}
Resumo: Na produção dissertativa tradicional, os alunos são orientados a não manifestarem declaradamente seu ponto de vista. Eles aprendem os caminhos para ocultar sua subjetividade. Na produção de resenhas, é necessário que o aluno deixe aflorar essa opinião a fim de criticar o objeto resenhado, visto que a crítica é um dos elementos constitutivos deste gênero. Portanto, o aluno precisa fazer o caminho inverso ao habitual e resgatar a subjetividade perdida. Este artigo intenciona verificar, a partir da análise de excertos de textos produzidos pelos próprios alunos, em aulas de produção de texto do gênero resenha, se houve apropriação de uma das seções importantes deste gênero, a crítica. Também faz parte da investigação deste artigo o uso de modalizadores textuais. A abordagem para a análise e produção de texto foi a dos gêneros discursivos ou textuais sobre a qual se fundamentou o trabalho de doutorado de que este artigo faz parte.
\end{abstract}

Palavras-chave: Subjetividade. Gênero discursivo. Produção de texto. Resenha.

\section{INTRODUÇÃO}

Este artigo de pesquisa é oriundo de meu doutorado ${ }^{1}$, que tratava da aplicação de uma sequência didática do gênero resenha a alunos (de 32 alunos matriculados, apenas 22 assistiram e participaram das aulas) de ensino médio de uma escola pública da periferia de Londrina. A aplicação

\footnotetext{
*Doutor em Estudos da Linguagem. Email: flaviofreire@hotmail.com

${ }^{1}$ Pesquisa orientada pela doutora Alba Maria Perfeito, professora do PPG em Estudos da Linguagem/UEL.
} 
foi feita por duas estagiárias do curso de Letras da Universidade Norte do Paraná (UNOPAR/Londrina), em 2010, e ao final solicitamos aos alunos a produção de resenha sobre o curta-metragem Ilha das Flores. Também foram feitas entrevistas com a professora e com alunos e anotações durante as aulas para triangular os dados para a pesquisa. $\mathrm{O}$ recorte feito aqui trata apenas da construção da crítica registrada pelos alunos em seus textos. Este trabalho objetiva, portanto, verificar como os alunos apresentaram um olhar particular - a crítica - sobre o filme, objeto proposto para resenha mediado pelo trabalho feito em sala de aula a partir da sequência didática.

É necessário, sob minha ótica, nos debruçarmos didaticamente sobre os gêneros a fim de propor caminhos aos alunos, sejam gêneros extraescolares, ou escolares. Não se aprende a trabalhar com eles simplesmente porque se está na escola ou na academia, portanto, é necessário investir nos gêneros escolares, uma vez que eles existem praticamente no ambiente estudantil. Matencio nos ajuda a entender o alvo que queremos atingir. A autora (2006, p. 100) assinala que

o que os resultados da pesquisa que temos desenvolvido têm demonstrado é que os problemas experienciados pelos alunos se originam, justamente, de sua dificuldade de perceber os traços que distinguem os modos de organização de funcionamento dos discursos científico e de divulgação daquele que caracteriza o discurso didático, que lhe é mais familiar.

Levando-se em conta que a língua significa não somente pelo conteúdo, mas também pela forma, é necessário habilitar o aluno a falar na "língua da escola/academia". A promoção é duplamente importante: é somente dessa forma que o aluno consegue obter êxito e é por esse caminho também que podemos investir em mais pesquisadores nas diversas áreas. $\mathrm{O}$ aluno alcança não somente outras formas de expressão linguística que vão permitir-lhe conviver no mundo acadêmico, mas vão abrir-lhe ainda portas de novas formas concretas de participação social como cidadão.

A opção pelo gênero resenha deu-se pelo motivo de ela ser não um texto apenas acadêmico, mas que também circula em jornais, revistas e internet, tendo como foco filmes, livros e $C D s$; ela permite ao cidadão comum ter ao seu alcance um instrumento de interpretação e crítica sobre o objeto em foco, como postula Rodrigues, R. H. (2000, p. 213): 
tendo em vista a função social de cada esfera e a singularidade de constituição e funcionamento de cada gênero, pode-se dizer que um projeto pedagógico para a produção escrita deve se orientar (sem excluir os demais) para aqueles gêneros cujo domínio é necessário para o bom desempenho escolar (saber tomar notas, fazer resumos, resenhas, participar de seminários, etc.) e para a plena participação na vida social pública.

Assim, a resenha instrumentaliza o indivíduo a olhar de forma mais exigente, podendo recorrer, inclusive, a várias resenhas sobre o mesmo objeto, a fim de compará-las. É um texto que permite, então, um comportamento mais crítico frente aos bens de consumo postos ao leitor, pelo viés da avaliação, seção importante na construção de uma resenha.

Como uma característica típica da resenha, a crítica lida com opiniões próprias e alheias. Em um segundo momento, espera-se que o leitor faça transferência dessa operação para outros textos e contextos, em um movimento de educação libertadora, em que lhe seja dada voz, como diz Silva (2005, p. 79-80; grifos do autor):

a leitura crítica é condição para a educação libertadora, é condição para a verdadeira ação cultural que deve ser implementada nas escolas [...]. Como empreendedor de um projeto, o leitor crítico necessariamente se faz ouvir. A criticidade faz com que o leitor não só compreenda as ideias veiculadas por um autor, mas leva-o também a posicionar-se diante delas.

Esse posicionar-se criticamente implica a função social de qualquer texto: dirigir-se ao outro, num processo de desvelar-se perante ele. Assim, a resenha é uma forma de ser-no-mundo, em que o aluno assume o que diz (sobre outro texto) para outros. Diferente de um texto apenas argumentativo, em que o autor discorre sobre um tema, aqui o autor precisa posicionar-se diante de e dialogar com outras obras e autores. Essa proposta, assumidamente política, vai ao encontro do que Geraldi (2001, p. 40) diz sobre qualquer metodologia adotada em sala de aula: "antes de qualquer consideração específica sobra a atividade de sala de aula, é preciso que se tenha presente que toda e qualquer metodologia de ensino articula uma opção". 
O contato que os alunos de ensino fundamental e médio podem vir a ter com resenha diz respeito àquelas veiculadas em jornais e revistas, portanto, as resenhas jornalísticas. A entrada dos diversos gêneros jornalísticos como objetos de ensino/aprendizagem permite trabalhar a realidade de mundo a partir da realidade textual, gerando condições para a criação de conhecimentos linguísticos e discursivos necessários à compreensão e produção de tais gêneros, como um caminho para a cidadania.

A escolha de filmes como objeto de resenha partiu da necessidade de adequação do projeto ao contexto. A princípio, a intenção era utilizar a literatura como objeto a ser resenhado, uma vez que os alunos precisam adquirir o hábito e gosto pela leitura e devem ler algumas obras para o vestibular, e tudo isso motivaria os alunos a lerem um livro para a produção da resenha. Mas, e se isso não acontecesse? Se eles simplesmente optassem por não ler o livro? A fim de evitar problemas futuros, a opção foi pelo filme, objeto sobre o qual haveria maior controle e que despertaria o interesse dos alunos em assistir e escrever.

Sempre defendi o uso de filmes em sala de aula, mas de curtasmetragens: a duração deles permite que se assista e discuta o filme em uma aula de 40 minutos, o que não acontece com um longa-metragem, que além de precisar de duas aulas ou mais (daí tomar-se emprestada aula de outro professor) apenas para a exposição do filme, necessitará de outra aula para a discussão. Assim, por vezes, a discussão é relegada ou feita apressadamente, como se o filme, por si, bastasse como recurso didático. Importante lembrar que um curta-metragem é tão bom e bem-acabado quando um longa-metragem; às vezes, até melhor, porque o diretor precisa concentrar toda a história em um período de tempo menor.

Em 1988, Jorge Furtado produziu Ilha das Flores, com duração de 13 minutos, financiado pela Casa do Cinema de Porto Alegre, para a Universidade Federal do Rio Grande do Sul, e que integra a coletânea Curta os Gaúchos. Este filme era para ser mais um documentário sobre tratamento de lixo. No entanto, Ilha das Flores satiriza as marcas textuais do modo expositivo de representação, distanciando o espectador, que, $a$ priori, espera uma leitura passiva em relação ao tema. 
Este curta é construído de forma hipertextual, em que as associações são as mais diversas, como a localização geográfica da colheita de tomates, as características humanas e suas diferenças para com o tomate e o porco, o surgimento do comércio e do dinheiro, a alimentação da família, doenças causadas por alimentos estragados, conceito de lixo, história e ilha (JESUS, 2005).

Em meio a tantas associações, percebe-se a ironia dos termos utilizados, bastante enciclopédicos, pondo a ciência como detentora do saber (JESUS, 2005):

Furtado impressiona ao usar de forma diferente termos cotidianos. A definição de dinheiro é associada a Cristo e este, ao judeu. Sincronicamente com a locução: 'os judeus possuem o telencéfalo altamente desenvolvido e o polegar opositor. São, portanto, seres humanos', aparecem imagens do holocausto. Na maior parte da película, o documentarista utiliza conceitos de dicionário. Até o momento em que se chega na Ilha das Flores: um vazadouro de lixo, onde mulheres e crianças esperam, do outro lado da cerca, os porcos terminarem para poder recolher o máximo de detritos em períodos de cinco minutos.

No início, Ilha parece um filme de ficção, mas vai mostrando o contrário no decorrer do texto. Da leveza e humor inicial, resta muito pouco ao fim do curta, bastante pesado e cortante, igualando-se à realidade que quer revelar.

$\mathrm{O}$ curta tem uma montagem peculiar e sofisticada, semelhante a outros filmes do diretor, como Meu tio matou um cara e $O$ homem que copiava. Há saturação de informações verbovisuais, que ora coincidem, ora se opõem. De início divertido e leve (veja a associação inicial criada pelo título do curta: Ilha das Flores (ambos semas positivos, o que dá margem ao trocadilho descoberto ao final do filme), vai se tornando denso à medida que o espectador se deixa envolver pelo narrador. Essa foi a estratégia assumida por Furtado (1992, p. 63): "para convencer o público a participar de uma viagem por dentro de uma realidade horrível, eu precisava enganálo. Primeiro, tinha que seduzi-lo e depois dar a porrada". 
Em Ilha das Flores, a construção dos argumentos se dá de forma textual e cinemática. É evidente que a escolha de imagens de estúdio ou congeladas hierárquica e ironicamente constrói o ponto de vista legitimado por Furtado. A consciência do filme acaba por substituir a nossa, numa trajetória de percepção e comprovação da realidade que "não se pode negar". O processo de construção de significados se sobrepõe aos significados construídos. Por todos esses motivos, por ser precursor de forma e de tema, escolhemos Ilha das Flores para a produção da resenha pelos alunos.

\section{GÊNERO RESENHA}

Peter Burke (2003) localiza o surgimento das resenhas no século XVII, em revistas cultas como o Journal des Savants, de Paris, e a Philosophical Transactions, da Royal Society, de Londres, veiculando conhecimento acadêmico. Em meio à febre de publicação pós-invenção da imprensa, produção intelectual e crescimento do mercado editorial comercial, era necessário um filtro para tais informações, difundido em revistas e jornais.

No Brasil, segundo Melo (2003), não era hábito o uso da palavra 'resenha', mas usava-se 'crítica' para a mesma função e, consequentemente, crítico para seu autor. Segundo ele (2003), o descompasso começou quando os intelectuais responsáveis pela análise crítica no campo das artes recusaram-se a vulgarizar seu trabalho e fazer concessões à indústria cultural. Foram, então, substituídos por jornalistas que não mais escreviam apenas ao intelectual, ampliando a abrangência da crítica da arte, tornando o gênero utilitário ao grande público. Os intelectuais começaram a perder espaço quando jornais e revistas deixaram de ser um produto de uma população restrita, consumidora de matérias bem elaboradas e críticas profundas, ao mesmo tempo em que o jornalismo atingiu a escala industrial na década de 30. O mesmo autor (2003, p. 129) define resenha, sob o viés jornalístico, como "uma apreciação das obras de arte ou produtos culturais, com a finalidade de orientar a ação dos fruidores ou compradores". 
Segundo Afrânio Coutinho (1975), a resenha é um texto jornalístico, um breve comentário da obra, enquanto crítica é bastante criteriosa para a peridiocidade dos jornais. Além disso, a resenha destina-se ao consumo popular e a crítica aos acadêmicos. Compreendida desta forma, em nossa realidade brasileira, a resenha parece orientar o público quanto aos produtos culturais postos em circulação, portanto, ocupa menos uma função intelectual que a versão original.

Do ponto de vista escolar, Machado, Lousada e Abreu-Tardelli (2004, p. 15) definem resenha como "[...] um texto que apresenta informações selecionadas e resumidas sobre o conteúdo de outro texto, trazendo, além das informações, comentários e avaliações do resenhista". É possível, a partir desta definição, ver a diferença entre resenha e resumo, porque aquela subsume este; o resumo integra a resenha. Além dele, outras seções da resenha seriam:

a) seleção de informações;

b) comentários do resenhista (ou resenhador);

c) avaliação do resenhista (ou resenhador).

Motta-Roth (2002, p. 90) traz algumas características essenciais para resenha, pinceladas em trabalhos de dois autores americanos do século passado. Para Drewry, uma resenha objetiva responder a questões básicas como autor, assunto, comparação com outras obras do mesmo autor, tema ou área. Steiner, em 1981, afirma que, quando se resenha um livro acadêmico, é preciso cobrir pontos essenciais como o cumprimento dos objetivos propostos, rigor com as referências e ortografia.

Com base nesses autores, Motta-Roth (2002, p. 91) postula que "há pelo menos dois tipos de informação necessária em Rs [resenhas]: 1) descrição do livro (p. ex., autor e utilidade para o leitor) e 2) avaliação dos pontos fortes e fracos do livro (p. ex., em que medida o livro cobre tópicos centrais e difíceis". Importante observar que, neste caso, trata-se de resenha acadêmica proveniente de livros e não de outros produtos culturais do cotidiano. Porém, estes mesmos objetos podem ser resenhados a partir de formatação semelhante.

Quanto às funções da resenha, Hunt (apud MELO, 2003) estabelece as seguintes: 
a) dar informações sobre os produtos do mercado cultural e suas qualidades;

a) elevar o nível cultural, uma vez que pontua criticamente tais qualidades;

b) reforçar a identidade cultural, uma vez que aprecia o produto a partir dos padrões geoculturais de seu público;

c) aconselhar como melhor empregar os recursos dos leitores, indicando produtos de baixa qualidade;

d) estimular e contribuir com artistas, elogiando seus trabalho e indicando as falhas;

e) definir o que é produto novo em relação à tendência dominante;

f) documentar o produto no momento histórico;

g) divertir, quando usa do humor, resgatando situações inusitadas.

Mais uma vez, as características da resenha parecem destoar do sentido original apontado por Burke, extrapolando o intelectual para alcançar, inclusive, o patamar lúdico.

Quanto às modalidades de resenha no âmbito do jornalismo, alguns autores, como Bond (apud MELO, 2003) apontam quatro categorias (clássica, relatorial, panorâmica e impressionista), enquanto outros, como Hunt (apud MELO, 2003), indicam apenas duas (autoritária e impressionista). A diferença básica para Bond, segundo Melo (2003), é que a clássica volta-se a estabelecer o novo com o já tradicional, a relatorial é mais descritiva, trazendo o sumário da obra e opinião implícita; a panorâmica emprega a perspectiva histórica e, por fim, a impressionista leva em conta os efeitos causados no ser humano. Para Melo (2003), há apenas dois métodos aí: um histórico e outro impressionista, visto que os outros dois são, na verdade, formas de exposição das informações.

$\mathrm{Na}$ Europa e Estados Unidos, intelectuais que dominam o texto jornalístico assinam as resenhas. No Brasil, o quadro é diferente, visto que jornalistas que se aventuraram e especializaram em determinada área são os responsáveis pelas críticas, que, às vezes, podem ser pesadas demais ou privilegiarem amigos (MELO, 2003). O gênero está em ascensão na mídia brasileira, não só escrita, mas mesmo televisiva, reflexo da expansão cultural pela qual passa o país e quantidade de novos bens culturais entrando em circulação, o que faz com que o leitor vá em busca de informações sobre eles. $\mathrm{O}$ espectro da resenha é bastante variado também, 
além dos produtos culturais tradicionais, como literatura, música, teatro, livro, artes plásticas, dança e cinema; absorveu também moda, gastronomia, esporte.

As categorias eleitas para análise dos textos produzidos pelos alunos durante o projeto foram baseadas nos aspectos de gêneros já conhecidos e aqui apenas retomados, a saber: a) tema ou conteúdo temático; b) estrutura composicional; c) marcas linguísticas e enunciativas ou estilo; d) contexto de produção.

O tema ou conteúdo temático do texto analisado apareceu sempre que se referiu ao curta- metragem, ou ainda assumiu outras expressões, como documentário, filme, ou apenas o curta, podendo também figurar como referências ao diretor do filme Jorge Furtado ou simplesmente Furtado.

Como estrutura composicional, foram levados em conta os dados da obra/autor, síntese (ou resumo) e crítica (ou avaliação). Neste caso, como se trata de um filme, esperava-se que os alunos incluíssem em seus textos quem era o autor (diretor) e outras obras dele. Essas informações foram provenientes de uma pesquisa solicitada aos alunos em um dos encontros, sobre Jorge Furtado, diretor do curta, e sobre sua carreira. Como não havia muita informação disponível sobre o diretor e sobre o curta, visto serem informações pontuais (biografia enxuta sobre o autor e premiações recebidas), as encontradas foram bastante repetitivas. Somou-se a isso o fato de os alunos que fizeram a pesquisa emprestaram-na a colegas. Portanto, houve semelhança entre os textos discentes, referentes a este tópico.

Na síntese, incluiu-se a capacidade de leitura deste texto fílmico, documentário crítico da realidade social do país, distinguindo o que seria a linha mestra de condução dos argumentos pelo autor. Como crítica, esperava-se ver comentários avaliativos, mesmo que superficiais, mas com base argumentativa.

As marcas linguístico-enunciativas do gênero em questão são mais discretas que em outros gêneros. Em parte, porque aqui se mescla um texto que deve ter argumentação, sem, contudo, ser tendencioso. Uma resenha deverá ser delimitada linguisticamente por marcas enunciativas que expressem a opinião do autor, modalizadores, operadores argumentativos com os quais se direciona a argumentação textual e adjetivos ou expressões adjetivas, acompanhados ou não de intensificadores. A fim de não nos 
desviarmos do nosso objetivo, preferimos não trabalhar com o conceito de operadores argumentativos com os alunos, mas utilizar os conceitos de coesão textual, adjetivos e advérbios, já conhecidos deles. Por isso, constam na ficha de avaliação o item "Uso de adjetivos e expressões para descrever" e o item "Uso dos elementos de coesão para argumentar no texto". São as marcas de opinião do autor que nos interessam neste texto, além dos operadores argumentativos.

Sobre o contexto de produção, importa destacar que a resenha normalmente é produzida com fins informativos, para a mídia ou para a academia, por profissionais da informação ou por pesquisadores, respectivamente; pode, ainda, como exercício, ser produzida por estudantes. Atualmente, publicam-se resenhas de filmes e livros na internet, por autores "amadores".

\section{DESCRIÇÃO DO MATERIAL DIDÁTICO}

Um primeiro critério a ser levado em conta na elaboração didática do material era o perfil dos alunos: adolescentes que gostam de música, videogame e televisão. Não gostam ou não têm o hábito de ler, portanto, resenha de livro não deveria ser nosso foco, ao passo que resenha de filmes seria interessante, se os filmes fossem direcionados a eles. Por consulta aos filmes mais vistos pelos adolescentes, chegamos a alguns. A maioria dos textos foi retirada da internet, por ser de fácil acesso e ser uma boa fonte de informações (principalmente de filmes e livros lançados recentemente). São eles:

1. sinopse do filme Crepúsculo (como é baseado em livro, poderia despertar o desejo pela leitura posterior); disponível em: $<$ http://www.cinemaemcena.com.br/Ficha_filme.aspx?id_critica=7392\&id filme $=3314 \&$ aba $=$ critica $>$, em 13/03/09.

2. sinopse da animação Monstros vs. Alienígena, em cartaz na época do projeto. Fez-se a escolha das sinopses para contraporem-se ao gênero em questão, a resenha; disponível em: $<$ http://www2.saudadefm.com.br/index.php?option=com_content\&view $=$ ca tegory\&id=36:filmes\&layout=blog\&Itemid=78>, em 13/03/09; disponível em: 
3. resumo do livro A menina que roubava livros, listado entre os mais lidos e vendidos na época da escolha, também para contrapor-se aos demais gêneros da sequência didática; disponível em: $<$ http://www.sinopsedolivro.com/2008/03/sinopse-do-livro-menina-queroubava.html>, em 13/03/09.

4. resenha do filme Crepúsculo, de internauta que viu o filme e postou a resenha; disponível em: $<$ http://centralrocknet.com.br/index.php?news=677>, em 12/03/09.

5. resenha do filme Crepúsculo, agora assinada por um aluno da Escola de Comunicação e Artes, da USP; disponível em: $<$ http://www.homemnerd.com/resenha.php?id=6594>, em 12/03/09.

6. resenha do filme brasileiro Se eu fosse você 2, campeã de bilheteria à época, escrita pelo jornalista e assessor de imprensa Caíque Gonçalves; disponível em:

$<$ http://recantodasletras.uol.com.br/resenhasdefilmes/1400305>, em 12/03/09.

7. resenha acadêmica do livro Bullying e desrespeito: como acabar com essa cultura na escola, tema bastante atual. De autoria de Gasparoni e Silva, alunas do quarto período de psicologia, esta resenha sofreu adaptações para se adequar ao propósito do projeto; disponível em: $<$ http://scielo.bvs-psi.org.br/scielo.php?pid=S167944272006000200011\&script=sci_arttext\&tlng=pt $>$, em 12/03/09.

8. resenha do show da cantora Bebel Gilberto, adaptada para o projeto. Assinada por Jan Fjeld e publicada na página do UOL Música. A adaptação priorizou a parte descritiva do show, bastante saliente neste texto; disponível em: $<$ http://musica.uol.com.br/ultnot/2005/08/10/ult89u5878.jhtm>, em 30/07/2013.

9. críticas publicadas no artigo Resenhas Podres, de Graieb, publicado na revista Veja, em 1999. O texto traz exemplos de críticas severas feitas a nomes como Machado de Assis e Drummond à época dos escritores (GRAIEB, C. "Resenhas podres", Veja, Abril, São Paulo, ed. 1619, ano 32, n. 41, p. 142-3, 13 de out. 1999). 
Além dos textos, na proposta havia exercícios de conectivos textuais, verbos, modalizadores, além de outros criados para análise dos textos da apostila. Um aporte com outras resenhas retiradas de jornais e revistas foi anexado ao material como de apoio ou leitura opcional.

Além disso, o material contou com uma ficha de autoavaliação para os alunos analisarem seus textos, e que serviu também para avaliação dessas produções pelos estagiários. Este quadro foi criado a partir dos elementos trabalhados com os alunos durante o projeto, como verbos e conectivos, mas também conta com elementos textuais básicos, tais como parágrafos e pontuação. Assim, traz mais pormenorizadamente os critérios para análise de uma resenha de filmes, sem abrir mão de elementos textuais que contribuem para a clareza do texto.

\section{Quadro 1 - Ficha de autoavaliação para resenha}

\begin{tabular}{|r|l|l|l|}
\hline \multicolumn{2}{|l}{ sim } & \multicolumn{1}{c|}{ não } \\
\hline 1 & Identificação (nome da obra) & & \\
\hline 3 & Ficha técnica & & \\
\hline 4 & Dados do autor/diretor & & \\
\hline 5 & Uesumo / descrição do conteúdo & & \\
\hline 6 & Comentário sobre a organização da obra (partes) & & \\
\hline 7 & $\begin{array}{l}\text { Linguagem usada: correção, clareza, objetividade, problemas de } \\
\text { tradução }\end{array}$ & & \\
\hline 8 & $\begin{array}{l}\text { Qualidade da contribuição, a quem se destina, sua utilidade, } \\
\text { comparação com outras obras do autor e de outros autores }\end{array}$ & & \\
\hline 9 & $\begin{array}{l}\text { Qualidade da produção: capa, material, fotografia, direção, música, } \\
\text { atuação dos atores, cenário, cortes etc. }\end{array}$ & & \\
\hline 10 & $\begin{array}{l}\text { Balanço das contribuições críticas e indicações de outras obras afins } \\
\text { (crítica com argumentos e bem-educada) }\end{array}$ & & \\
\hline 11 & Uso de verbos para indicar a ação do autor sobre o texto & & \\
\hline 12 & Uso dos elementos de coesão para argumentar no texto & & \\
\hline 13 & Texto dividido em parágrafos ordenadamente & & \\
\hline 14 & Parágrafos divididos em frases completas & & \\
\hline 15 & Pontuação adequada (vírgulas, pontos etc.) & & \\
\hline 16 & Concordância correta & & \\
\hline 17 & Ortografia e acentuação verificadas & \\
\hline
\end{tabular}

Fonte: Elaboração do autor. 
A avaliação crítica, parte integrante das resenhas, contribuiu para discussão e modelo da crítica que deveria haver nas produções discentes.

\section{METODOLOGIA}

A pesquisa só pode ser entendida e explicada a partir de seu contexto de produção. Os paradigmas criados para análise não são artefatos naturais, mas instrumentos criados para explicar e compreender os fenômenos da natureza e da sociedade.

Como parte fundamental da resenha, na sequência didática utilizada no projeto, previu-se o trabalho com a crítica. Frisou-se a necessidade de uma crítica bem fundamentada, livre de "achismos", uma vez que seria cobrada posteriormente na produção de texto dos alunos. Para tanto, análises de críticas nas resenhas dadas (de filmes e livros, mais e menos formais) foram bastante recorrentes, bem como casos de críticas sem fundamento colocadas a público. Nessas análises, destacou-se o modo como o texto manifesta o ponto de vista dos autores, a avaliação sobre o objeto resenhado, com a observação dos efeitos provocados pelo uso dos adjetivos, modalizadores, da escolha dos substantivos e demais elementos linguísticos.

Em seguida às análises linguísticas, os alunos assistiram ao curtametragem Ilha das Flores e foi feita uma discussão do filme a fim de que a interação pudesse contribuir com aspectos não percebidos pelos alunos, mas destacados pelos colegas. Após, lhes foi solicitado que escrevessem uma resenha sobre o vídeo, ao que se pediu conferência com o quadro de autoavaliação de resenha e posterior refacção textual.

Finalizados os textos, fizemos, para o artigo em tela, o recorte dos excertos que demonstravam como tinham visto o curta em questão e como se colocavam diante dele textual e criticamente. Os modalizadores também foram listados. 


\section{A CRÍTICA E A VOZ DOS ALUNOS}

Alguns autores dizem que a resenha deve ser feita por especialistas, visto que eles é que teriam conhecimento suficiente para avaliar, comentar, comparar um livro ou filme. Isso é bastante coerente. Afinal, apenas um especialista poderia comparar uma obra com outras do mesmo autor ou de autores diferentes. Só um especialista teria autoridade para a crítica. Então, por que a resenha de um livro de literatura brasileira é pedida para um aluno que não é especialista, e talvez nunca o seja? Por ser um exercício acadêmico e político. Souza e Carvalho (1999) corroboram, afirmando que "as recensões variam na forma e no conteúdo de acordo com a qualificação do seu autor" (p. 55), utilizando recensão como sinônimo de resenha crítica. Outra justificativa é que nem sempre foi assim.

Um movimento de jovens denominado "política dos autores", surgido a partir de um texto de Truffaut, em 1954, legitimou a crítica de cinema:

o trabalho do crítico a partir de então ganha o propósito de contribuir na formação de um espectador reflexivo, analítico e crítico, que deveria tomar uma atitude ativa frente ao que assistisse na tela, contando com novos e específicos conhecimentos para opinar sobre uma obra fílmica (ALTMANN, 2008, p. 4).

Assim, a crítica de cinema era feita por profissionais e amadores ou amantes do cinema, num ritual de não apenas contemplar, mas também de refletir sobre. Para Altmann (2008, p. 6), "essa possibilidade de escrever sem teorias de respaldo pode ser vista como uma vantagem e não uma deficiência, pois a ausência de método teria aberto um espaço inédito para a reflexão que não se restringia ao crítico, mas se estendia e formava o próprio espectador".

Além disso, Altmann ainda chama a atenção para o fato de que a crítica passa por um momento de "laicização e democratização ganhando uma ampliação do campo não apenas na imprensa generalista mas em espaços não institucionalizados, como os meios eletrônicos, por exemplo" (2008, p.7). Em uma realidade inédita de tornar públicas as muitas vozes que querem falar, impossível restringir a apenas alguns a autoridade da palavra. 
Quando solicitamos aos alunos que fizessem a avaliação do curta exibido, como parte integrante da resenha, demos a eles a oportunidade de assumirem sua voz no texto. Esperávamos, como dissemos acima, que comentários avaliativos aparecessem no texto, ainda que superficiais, porém, com base argumentativa.

Entre os autores, cinco manifestaram-se declaradamente, usando a expressão "na minha opinião" (2, 8, 9, 11 e 14). Quando tratamos de resenha, não se indica tradicionalmente que a opinião seja tão marcadamente expressa, visto que há estratégias discursivas que permitem um enfraquecimento da manifestação autoral. O ideal é que os alunos conheçam as possibilidades dentro da língua e escolham que estratégias desejam utilizar, de acordo com objetivos e contextos. Coracini, em Um fazer persuasivo: o discurso subjetivo da ciência (2007), discute a manifestação da subjetividade nos textos acadêmicos, que aparece mesmo naqueles que julgam deixá-la de lado. Ainda a esse respeito, é bom lembrar que certos direcionamentos de redação para vestibular desvalorizam a emersão do sujeito.

Em minha dissertação de mestrado (RODRIGUES, F. L. F., 2000), discuti sobre o assujeitamento do aluno por meio das redações escolares com alunos de oitava série. A conclusão a que cheguei da análise de redações produzidas por eles era de que "todos os alunos são autores, todos os textos têm unidade de sentido, porém essa unidade parece-me prédeterminada, fixada pela escola" (2000, p. 108). No caso atual, a resenha dá oportunidade, e até exige, que os alunos manifestem seu ponto de vista, na tentativa de fazer com que eles produzam textos para a escola, e não $n a$ escola, como conjectura Geraldi (2013). Isso não quer dizer que a escola tenha deixado de impor um padrão de linguagem, além de um padrão de referências para pensar e interpretar a realidade (PÉCORA, 1992), mas que, como Possenti (1996) argumenta, há sujeitos ativos, nem totalmente livres, nem totalmente assujeitados, cuja ação dar-se-ia em um espaço encontrado pelo sujeito para manifestar-se.

Cremos que a resenha possa ser um destes espaços para o aluno, até porque a expressão "na minha opinião" não apareceu em nenhum dos textos trabalhados com os alunos durante as análises, sendo, portanto, um aporte dos próprios autores. 
Na produção textual solicitada, objetivava-se o desenvolvimento do autor crítico, que assumisse a responsabilidade pelo seu discurso. Seria o caso, por exemplo, de uma construção muito interessante no texto $10^{2}$ : “o texto começa com uma lavoura passa pela área urbana e acaba com um disperdício". Pode-se perceber a capacidade de síntese do aluno, que vai além dos seus colegas de sala e mesmo de alguns textos de alunos universitários que têm dificuldade de sintetizar. E chamou-me a atenção não apenas a síntese, mas o modo como textualmente foi construída. Há algo autoral aqui.

Em contraponto, há outro texto que deixa emergir a voz do autor de forma pouco agradável. No texto 4, o aluno parece querer constranger o leitor do texto, estagiárias ou professora, lançando mão da avaliação: "eu acho que esse filme é uma merda", assumindo o tom agressivo explicitamente. Não deixa de ser a voz intencional de um sujeito se fazendo presente, talvez insatisfeito com a obrigatoriedade de produção textual ou ainda porque o vídeo manifesta uma realidade muito agressiva para o aluno: "valoriza mais os porco" (texto 4) [que o ser humano].

Mas como dito há pouco, a minoria dos alunos permitiu manifestarse "autoralmente" no texto, isto é, poucos fazem explicitamente sua avaliação ao curta, colocando-se no texto. O que, porém, não impede que algumas construções indicadoras de avaliação, ainda que implícita, como há em alguns textos, apareçam de forma diluída, como no texto 7: "o nome Ilha das Flores so tem nome porque de flor não tem nada", "isso não é so naquela epoca", "não so no Brasil isso mais sim no mundo". A passividade revelada pela omissão de elementos demarcadores dos limites da voz do próprio autor preferida por alguns alunos, provavelmente se dê pelo intenso reforço da escola de que texto dissertativo deve ser sempre impessoal.

Em certo momento, a professora mostrou-se preocupada pelo fato de as estagiárias não terem dito aos alunos que no curta apresentado havia crítica social, temerosa de que eles não a percebessem. Acredito que a preocupação da professora tenha sido justa, porém, nossa opção foi por deixar que os alunos exercessem a percepção quanto ao que sentiam e pensavam sobre o vídeo. Não queríamos, de antemão, dar categorias já

\footnotetext{
${ }^{2}$ Os recortes serão transcritos tais como produzidos.
} 
prontas para os alunos: eles deveriam buscar, no conhecimento que traziam, os modos de interpretação para aquele texto. E esses modos apareceram. Alguns alunos interpretaram o curta com foco na questão do desperdício de alimentos, outros na miséria da realidade mostrada no documentário. $\mathrm{O}$ Quadro 2, mais a frente, ajuda a verificar que, de uma forma ou outra, eles demonstraram textualmente a crítica social do curta:

Se a crítica é um elemento essencial na resenha, os alunos demonstraram tê-lo percebido e utilizado. Ao mesmo tempo em que tal ponto positivo aparece nos textos, manifestam-se outras dificuldades textuais, acúmulo de malsucedidas aulas de Língua Portuguesa.

Os modalizadores também aparecem nos textos e marcam a voz e a modalização do autor do texto em relação ao que é dito, por isso achamos importante destacar como os alunos os utilizaram, porque ainda é uma marca de autor. Os números identificam os textos produzidos pelos alunos, os mesmos apontados no quadro acima.

No segundo texto, aparecem algumas marcas linguísticoenunciativas: os verbos modalizadores "podem se ver", "pode-se ver", "podem ser aproveitados", "não devemos chogar", "gostaria de passar", demonstrando que o autor usa bastante o recurso de modalizar seu discurso:

- Vocês podem se ver que na Ilha não tem nada de flores mas muito lixo: pode-se ver também que na ilha das flores tem um terreno que há um dono que cria porcos

- Bom em minha opinião o diretor gostaria de passar que isso é a realidade que acontece na "Ilha das flores": e também não devemos chogar alimentos que podem ser aproveitados...

Marcas linguísticas e enunciativas constantes no texto 4 são os dois modalizadores, "aí sim" e "eu acho". Quando o autor introduz sua crítica com "eu acho que", está explicitando sua voz, o que poderia ser omitido se usasse outra estratégia, como, por exemplo, simplesmente omitir a expressão. Tal recurso é execrado quando se discute redação para o vestibular.

- E o outro alimento que os porcos não comem, aí sim vão para o seres humano de clase Baixa (Baixa renda).

- Eu acho que esse filme é uma merda. 


\section{Quadro 2 - Crítica observada e registrada pelos alunos}

\begin{tabular}{|c|c|}
\hline Texto & Transcrição \\
\hline 1 & retrata no desperdicio das pessoas miséria, e o lixo \\
\hline 2 & $\begin{array}{l}\text { realidade que acontece na "Ilha das flores": e também não devemos chogar } \\
\text { alimentos que podem ser aproveitados }\end{array}$ \\
\hline 3 & $\begin{array}{l}\text { trata sobre o tomate e os seres humanos que não tem condição } \\
\text { pobres que ficam no lixão catando resto de legumes e verduras para sobreviver }\end{array}$ \\
\hline 4 & porque (s.i.) o seres humano e valoriza mais os porco \\
\hline 5 & $\begin{array}{l}\text { mostra a realidade brasileira de pessoas que comem restos de lixos e que passam } \\
\text { fome }\end{array}$ \\
\hline 6 & bom para abrir os olhos da sociedade quanto aos problemas que existe no país \\
\hline 7 & $\begin{array}{l}\text { fala da miséria, sobre o tomate, da família, do dinheiro, restos de comida } \\
\text { desperdiçados pelo homem } \\
\text { ate hoje por exemplo vemos nas ruas vemos crianças aduto muitas vezes fuçando } \\
\text { no lixo a procura de alguma para come e vesti e não so no Brasil isso mais sim no } \\
\text { mundo todo }\end{array}$ \\
\hline 8 & $\begin{array}{l}\text { relata uma realidade que poucas pessoas admitem existir, a miséria e o desperdísio } \\
\text { de alimento no nosso país }\end{array}$ \\
\hline 9 & $\begin{array}{l}\text { a realidade desse mundo ver que as pessoas de classes média não dão valor a } \\
\text { comida, mais quem não tem dinheiro entende o valor de um tomate, de uma comida }\end{array}$ \\
\hline 10 & para toda a população se concientizar de que não é bom desperdiçar alimento \\
\hline 11 & $\begin{array}{l}\text { gostei de ver a realidade mas não gostei de ver as pessoas sofrendo de fome, ver } \\
\text { que as pessoas são piores que animais }\end{array}$ \\
\hline 12 & pode dar uma ideia de reflexão sobre as coisas \\
\hline 13 & $\begin{array}{l}\text { está preocupado com a situação do Brasil, este curta usa falta de condições } \\
\text { financeiras }\end{array}$ \\
\hline 14 & $\begin{array}{l}\text { um lugar que só existe sujeira, miséria e pobreza... } \\
\text { mostra a realidade de disperdício de alimentos que poderiam ser evitados }\end{array}$ \\
\hline 15 & $\begin{array}{l}\text { mostra a realidade do Brasil } \\
\text { bom para mostrar a realidade da sociedade }\end{array}$ \\
\hline 16 & $\begin{array}{l}\text { alimentos bons para os porcos e o que não serviam para os porcos eles dão para as } \\
\text { pessoas que prescisa }\end{array}$ \\
\hline 17 & $\begin{array}{l}\text { mostra a realidade muito triste e da pena dessas pessoas, esse curta mostra quanto } \\
\text { devemos dar valor a nossas coisas }\end{array}$ \\
\hline 18 & $\begin{array}{l}\text { mostra sobre a questão social miserável, a realidade de vida de pessoas que comem } \\
\text { o que se julga adequado a alimentação dos porcos }\end{array}$ \\
\hline 19 & mostrar as pessoas a realidade e acordar a sociedade para os problemas \\
\hline 20 & $\begin{array}{l}\text { só tem nome bonito e vi muita mizéria e pobreza até os porcos comiam melhor que } \\
\text { os seres humanos }\end{array}$ \\
\hline 21 & Pessoas pobres que na escala de prioridade são piores que os porcos \\
\hline 22 & Um curta feito unicamente para mostrar a pobreza \\
\hline
\end{tabular}

Fonte: Elaboração do autor. 
No sétimo texto, aparece a marca linguístico-enunciativa/ modalizador "eu acho":

- Por isso que eu acho que isso não é so naquela epoca, e sim ate hoje.

Ainda que seja breve, o texto 8 traz ao final o modalizador "na minha opinião", uma marca linguístico-enunciativa que, como já dissemos, deve ser omitida em textos argumentativos para vestibular. Ainda aparecem os adjetivos "verdadeiro" e "triste" e o relativizador com função modalizadora "certa" para referir-se à agressão:

- Na minha opinião o curta foi verdadeiro mas teve uma serta agreçao eu quanto asisti fiquei muito triste.

Já no primeiro parágrafo do texto 9, o autor usa o advérbio "mundialmente" com função modalizadora:

- Jorge Furtado é conhecido mundialmente, e com esse curta ele pode mostrar não só a origem do tomate como pode mostrar a realidade do ser humano.

O advérbio "parcialmente" é usado no décimo texto como modalizador para referir-se à autoridade do diretor do curta:

- Jorge Furtado, parcialmente autoridade cursou medicina, psicologia, jornalismo e artes plásticas, foi reporter, editor, presentador, roteirista e produtor.

No texto 13, o autor usa o verbo tentar em "ele tenta se aproximar do real", como modalizador e marca sua posição frente à total possibilidade de o curta assemelhar-se ao real, afastando-se do enunciado. A expressão "para mim", que introduz sua avaliação, marca explicitamente a voz do autor no texto:

- Este curta usa falta de condições financeiras, assim como suas outras obras ele temta se aproximar do real. 
O modalizador "só" orienta a argumentação no texto 14 para a afirmação total: "na Ilha só existe sujeira, miséria e pobreza". O modalizador "na opinião dela" atribui a avaliação do tomate à D. Anete, personagem do curta, eximindo o autor de assumir a culpa pelo desperdício do alimento. No último parágrafo, o autor assume a avaliação do curta, que pode ser passível de dúvida, com o modalizador "na minha opinião". Também neste parágrafo, o verbo modalizador "poderiam" indica a possibilidade de se evitar o desperdício de alimentos:

- Ele é um ótimo diretor e só faz filmes bons e isso é comprovado com os vários prêmios que ele já ganhou.

- A Ilha das Flores é um lugar que só existe sujeira, miséria e pobreza.

- Na minha opinião esta narrativa foi muito interessante e bem organizada porque mostra a realidade de disperdício de alimentos que poderiam ser evitados.

No texto18, aparecem algumas marcas linguístico-enunciativas. O advérbio no sintagma "grandemente premiado" indica, como modalizador, a apreciação do locutor sobre o conteúdo:

- Jorge Furtado, também conhecido por outros filmes de suceso como, meu tio matou um cara, cidade dos homens, entre outros, é grandemente premiado por suas obras

O advérbio "parcialmente", modalizador, parece indiciar a intenção do autor do texto 19 de relativizar a autoridade do diretor. Acredito que o autor tenha usado indevidamente este advérbio, uma vez que ele qualifica outro vocábulo usado fora de sentido "autode data" (autodidata). Suponho que tenha assimilado a expressão de outro contexto ou texto:

- Jorge Furtado parcialmente autode data cursou medicina, psicologia, jornalismo e artes plásticas com o filme "ilha das flores" ganhou o prêmio "uso de ouro" na Alemanha, foi repórter, escritor, apresentador e roteirista. 
Algumas marcas aparecem no texto 20. O modalizador "por exemplo" concretiza, provando, um dos importantes prêmios alcançados pelo diretor do curta. $\mathrm{O}$ verbo bastar no imperfeito "bastaria" modaliza e indica a probabilidade de se conseguir o mesmo resultado filmando cenas cotidianas reais:

- O diretor do curta Ilha das Flores, Jorge Furtado ganhou varios prêmios por exemplo o Urso de Ouro na Alemanha

- Se ele quisese mostrar a pobreza do Brasil bastaria colocar uma câmera na calçada de sua casa.

\section{CONSIDERAÇÕES FINAIS}

O ponto de partida do trabalho era de que os gêneros pudessem ser um caminho de sucesso nas aulas de língua portuguesa, porque ampliam o repertório dos alunos, dando-lhes oportunidade de ler, analisar e produzir textos que realmente existem fora da escola, num movimento que evoca Bakhtin: "a língua penetra na vida através dos enunciados concretos que a realizam, e é também através dos enunciados concretos que a vida penetra na língua" (BAKHTIN, 1992, p. 282).

Neste âmbito, a resenha é um gênero que permite ao aluno o contato com vários bens culturais que circulam na sociedade e que precisam de um olhar crítico sobre eles. Isso permite não só uma seleção melhor no momento da escolha e consumo de tais bens, mas também permite exercitar a criticidade, que raramente tem encontrado caminhos na escola. Essa criticidade, se falamos em produção de resenha, requer que o aluno reflita e argumente, não apenas emitindo uma opinião imponderada, o que contribui na produção de textos dissertativos também, tão caros às aulas de redação. E talvez o mais importante, que o aluno assuma seu discurso, com o peso e a responsabilidade advindos dele.

Um dos objetivos do texto era verificar se e como as críticas, após trabalhadas na sequência didática do gênero resenha, apareceriam nos textos dos alunos. A constatação final é que poucas críticas explícitas surgiram; construções indicadoras de avaliação implícita figuram, o que 
poderia indicar uma voz contida, abafada pelo sistema escolar, ou falta de prática de uma olhar crítico, ou ainda que a sequência didática não tenha trabalhado suficientemente esta questão.

Outro objetivo era o levantamento do uso dos modalizadores. Até pela extensão da análise deste tópico, é possível perceber que os alunos têm mais facilidade no seu uso do que em manifestar opinião própria (crítica). Como a escola trabalha com modalizadores, conectivos, elementos de coesão e outros nomes e categorias que podem compor o quadro dos modalizadores, e mesmo o uso intuitivo pelo aluno, é possível justificar a maior presença deles no texto do que a crítica. A função da sequência em tela, então, foi tornar claros os efeitos de sentido produzidos por esses elementos nos textos.

A partir dos resultados deste trabalho, penso que seria interessante se houvesse mais tempo e atividades previstas para se trabalhar com modalizadores textuais na sequência didática proposta. Além de ser um recurso fundamental para outros textos, como os argumentativos, é também um descritor de subjetividade e crítica; infelizmente é pouco conhecido dos alunos quanto aos efeitos de sentido. Às vezes, eles aparecem nos textos que lemos em sala de aula, mas não refletimos sobre seu uso e sentido.

Por fim, gostaria de acrescentar que penso ser importante que trabalhemos com filmes em sala de aula, mas que eles sejam objeto de reflexão e análise. Como já dito antes, nossos alunos crescem frente à TV vendo filmes mais que lendo livros, então, dar a eles um instrumento de avaliação e crítica frente a esses produtos culturais seria dar-lhes uma chave, não apenas de interpretação, mas de escolha de que produtos consumir. O cinema tem sido foco de investigação nos últimos tempos e novas publicações têm chegado às prateleiras, ajudando o espectador a entender melhor a linguagem do cinema, como a produção e o mercado consumidor. Produtos culturais exigentes de mais experiência do leitor, como literatura e cinema fora do circuito comercial, precisam ser explorados na escola. Ninguém nasce sabendo e não se gosta daquilo que não se conhece ou que não faz sentido. 


\section{REFERÊNCIAS}

ALTMANN, E. Recepções da crítica cinematográfica. 2008. disponível em: $<$ http://www.cult.ufba.br/enecult2008/14272.pdf>. Acesso em: 12 fev. 2009. BAKHTIN, M. M. Problemas da poética de Dostoievski. São Paulo: ForenseUniversitária, 1992.

BURKE, P. Uma história social do conhecimento: de Gutemberg a Diderot. Rio de Janeiro: Jorge Zahar, 2003.

CORACINI, M. J. R. F. Um fazer persuasivo: o discurso subjetivo da ciência. 2. ed. São Paulo: Pontes/Educ, 2007.

COUTINHO, A. Da crítica e da nova crítica. 2. ed. Rio de Janeiro: Nova Fronteira, 1975.

FURTADO, J. Um astronauta no Chipre. Porto Alegre: Artes Ofícios, 1992. . (Dir.). Ilha das Flores. Brasil: Sagres, 1988. Parte da coletânea Curta os gaúchos. Disponível em: <http://www.youtube.com/watch?v=bVjhNaX57iA $>$. Acesso em: 17 maio 2012.

GERALDI, J. W. Concepções de linguagem e ensino de português. In: GERALDI, J. W. (Org.). O texto na sala de aula. São Paulo: Ática, 2001. p. 39-46.

. Portos de passagem. 5. ed. São Paulo: Ática, 2013.

JESUS, R. M. V. de. Ilha das Flores: o documentarista em primeiro plano. www.oolhodahistoria.ufba.br - Edição $\mathrm{N}^{\circ}$ 8. 2005. Disponível em: $<$ http://www.oolhodahistoria.ufba.br/artigos/ilha-das-flores-rosane-meira-vieirade-jesus.pdf $>$. Acesso em: 25 jul. 2012.

MACHADO, A. R.; LOUSADA, E.; ABREU-TARDELLI, L.S. Resenha. São Paulo: Parábola, 2004.

MATENCIO, M. L. M. Letramento na formação do professor: integração a práticas discursivas acadêmicas e construção da identidade profissional. In: CORRÊA, M. L. G. e BOCH, F. (Orgs.). Ensino de língua: representação e letramento. São Paulo: Mercado de Letras, 2006. p. 93-105.

MELO, J. M. de. Jornalismo opinativo. 3. ed. Campos do Jordão: Mantiqueira, 2003.

MOTTA-ROTH, D. A construção social do gênero resenha acadêmica. In: MEURER, J.L.; MOTTA-ROTH, D. (Orgs.). Gêneros textuais e práticas discursivas. Bauru: EDUSC, 2002. p. 77-116.

PÉCORA, A. Problemas de redação. 4. ed. São Paulo: Martins Fontes, 1992.

POSSENTI, S. O sujeito fora do arquivo. In: MAGALHÃES, I. (Org.). As múltiplas faces da linguagem. Brasília: UNB, 1996. 
RODRIGUES, R. H. O artigo jornalístico e o ensino da produção escrita. In: ROJO, R. (Org.). A Prática de linguagem em sala de aula: praticando os PCNs. São Paulo: Mercado de Letras, 2000. p. 207-220.

RODRIGUES, F. L. F. A (in)constituição do sujeito pela escola. 2000.119 f. Dissertação (Mestrado em Letras) - Curso de Pós-graduação em Letras, Universidade Estadual de Londrina, Londrina, 2000.

SILVA, E. T. da. $O$ ato de ler: fundamentos psicológicos para uma nova pedagogia da leitura. 10. ed. São Paulo: Cortez, 2005.

SOUZA, L. M.; CARVALHO, S. W. Compreensão e produção de textos. 4. ed. Petrópolis: Vozes, 1999.

\section{Recebido em: 09/10/2012. Aprovado em: 12/08/13.}

Title: The construction of criticism in reviews produced by students Author: Flávio Luis Freire Rodrigues

Abstract: Usually, the production of texts by the students is guided by the school not to openly express their opinion or point of view. They learn the ways to hide their subjectivity. In the production of reviews, one must let the students express their opinion in order to criticize the subject reviewed, since criticism is one of the constituent elements of such a genre. Therefore, students are asked to do the opposite way and rescue their lost or forgotten subjectivity. This article discusses how this issue has been worked with high school students in the writing of reviews in classes of text production at a public school in Londrina, by analyzing their texts. We also want to investigate how students use the modal verbs in their texts. The approach used in the analysis and text production by students was the discursive or textual genres. This paper was a part of my doctoral work.

Keywords: Subjectivity. Gender Discourse. Text production. Review.

Título: La construcción de la crítica en reseñas producidas por alumnos

Autor: Flávio Luis Freire Rodrigues

Resumen: En la producción disertadora tradicional, los alumnos son orientados a no manifestar declaradamente su punto de vista. Ellos aprenden los caminos para ocultar su subjetividad. En la producción de reseñas, es necesario que el alumno deje aflorar esa opinión con el fin de criticar el objeto reseñado, visto que la crítica es uno de los elementos constitutivos de este género. Por lo tanto, el 
alumno precisa hacer el camino inverso a lo habitual y rescatar la subjetividad perdida. Este artículo intenta verificar, a partir del análisis de partes de textos producidos por los propios alumnos, en clases de producción de texto del género reseña, si hubo apropiación de una de las secciones importantes de este género, la crítica. También hace parte de la investigación de este artículo el uso de modalizadores textuales. El abordaje para el análisis y producción de texto fue la de los géneros discursivos o textuales sobre la cual se fundamentó el trabajo de doctorado del que este articulo hace parte.

Palabras-clave: Subjetividad. Género discursivo. Producción de texto. Reseña. 